\title{
ATMOSPHERE OF SOCIETAL ANXIETY AND REPRESENTATIONS OF THE BODY: THE IMAGE OF MAN IN SURREALIST WORKS OF VÍTĚZSLAV NEZVAL IN THE 20TH CENTURY INTERWAR PERIOD IN BOHEMIA
}

\author{
ANNA BRZEZIŃSKA \\ Institute of Slavic Studies, University of Wrocław \\ ul. Pocztowa 9, 53-313 Wrocław Poland \\ e-mail adress: brzezinska.ann@gmail.com
}

\begin{abstract}
Aim. The interwar period in Czechoslovakia was a time of societal anxiety. The aim of this paper is to find the central themes of societal fear, as reflected in the surrealist works of Vítězslav Nezval, a czech poet. The analysis will be based primarily on the lyric poetry from the collections: Žena v množném čísle [Woman in Plural] (1936) and Absolutní hrobar [Absolute Gravedigger] (1937).

Methods. The analysis is based on the Josef Vojdovík's anthropo-phenomenological method of exploring the surrealist perceptions of the body, which is based on vertical and horizontal anthropological dimensions and phenomenological conceptions of fears.

Results. Surrealist poetry and other literary works contain images of the body that are changed by fear: deformations, metamorphoses, fragmentarisations, hybridisations, expressing the body as a collage, a mosaic, an amalgam, a phantom, a grotesque, an inlay, and as lifelessness. It undergoes multiple metamorphoses, not only within its own form, but also with regard to the categories of life and lifelessness.

Conclusions. The analysis leads to the conclusion, that V. Nezval's works show a clear tendency to portray the body as an object which undergoes a metamorphosis. The body is balanced on the edge between living and dead, organic and inorganic, it is determined by time and space. It is often shown along the narrowing-widening relation, in stupor, petrification, reduced to a flat surface or miniaturised.

Key words: czech surrealism, Vítězslav Nezval, social anxiety, Absolute Gravedigger, Woman in Plural, metamorphosis,
\end{abstract}

\section{INTRODUCTION}

The interwar period in Czechoslovakia was a time of societal anxiety caused by the formation of the early fascist and totalitarian groups. The event that had the most significant impact on the works of art created in that period was the occupation of the Protectorate of Bohemia and Moravia by Nazi Germany. The works of surrealists show a clear tendency, which was best summarized 
by Josef Vojvodík (2007, p. 71): "The world of common, trivial objects, which create the space of everyday life - objects that were solemnly introduced into art, in all their absolute uniqueness, before World War I (...) and during the 1920 s, as a product of the $>$ new « beauty of modernity (...), is now anthropomorphised, with its objects becoming deceptive, double-faced agents of the » ordinary « nonsense reality of war." The fascination with human civilization and its achievements in the age of poetism and in the face of the war machine are utterly deconstructed. Inventions and technological milestones become sources of dread. It is no longer possible to predict the course of action that mankind will take next, since humans proved to be capable of orchestrating such tragedies as a world war (Vojvodík, 2007, p. 72).

According to Jan Mukařovsky (1966, pp. 272-273), the purpose of a literary work is to react to the changing reality. This seems to also apply to the Czech surrealists, who were creating their works in Prague during the 20th century interwar period. The aim of this paper is to find the central themes of societal fear, as reflected in the surrealist works of Vítězslav Nezval, a poet, writer, and the founder of the Prague surrealist movement. The analysis will be based primarily on the lyric poetry from the collections: Žena v množném čísle [Woman in Plural] (1936) and Absolutní hrobař [Absolute Gravedigger] (1937).

\section{AVANT-GARDE VIEWS OF THE BODY}

At the turn of the 19th century, the body was perceived as flawed; it was commonly believed that harmony can be achieved only thanks to the intellect, which was to control the corporeal imperfections. With time, however, the poetistic ideas were buried under the advancing wave of criticism and were no longer reflected in the world consumed by an atmosphere of fear. All constructive plans were redefined to fit a new reality; thus, giving way to the idea of existence that is out control, and consciousness that is constantly threatened by absurdity, death, dread, and madness (Vojvodík, 2007, p. 58-59).

Even the vertical and horizontal anthropological dimensions of the literary works show that poetists were especially interested in dimensions connected with upward motion - raising, lifting (which all have positive connotations). In surrealist works, on the other hand, references to falling, descent, and the abyss dominate, which is a reflection of the dimension of depth, connected to the fear of unpleasant burden. In poetistic works, acrobatics, circus tricks, flying, and gliding all have positive connotations, while in surrealism they are perceived as a threat, which is further escalated by the fear of falling into nothingness, and of balancing on the edge of being and non-being (Vojvodík, 2007, p. 60).

The avant-garde, as the name itself implies, was seeking new forms of artistic expression, which was connected primarily with the redefinition of the interrelations between the body, art, and society. New philosophical and aesthetic trends, along with the achievements in social sciences and natural sciences, have severed the connection between the body and the category of 
harmony. "Due to the dominant influence of the intellect, achieving unity of body, intellect and psyche proves to be impossible, perhaps even precarious. The body suddenly becomes a ruin: fragmentary, sick, sensuous, and ecstatic" (Heczková, Plívová, 2001 p. 368). The mentally ill, with their uncontrollable seizures and hysterical fits, became an object of fascination. Convulsive, spastic movements were deemed to be the new semantic gesture, and a theme for artists who used it to express themselves (Heczková, Plívová, 2001 p. 369).

Most importantly however, the role of the body in the avant-garde movement was not supposed to be reduced only to that of an artistic theme. The body was given a more important role; it became the third "central anthropological constant of human existance" (Heczková, Plívová, 2001 p. 369), along with space and time.

\section{JOSEF VOJVODÍK'S ANTHROPOLOGICAL METHOD AND ITS PHILOSOPHICAL ROOTS}

In his book titled Imagines corporis. Tělo v českémoderněa avantgardě, Josef Vojvodík, a contemporary researcher of the avant-garde movement, has proposed his own anthropo-phenomenological method of exploring the surrealist perceptions of the body. To fully understand its implications, it is necessary to emphasise the fact that the anthropological model adopted by the surrealists was a combination of the body, time, and space, in which being is a narrative about humans and their way of existence, and is based on such ontological questions as "what kind of a human being am I?" and "who am I in relation to others?". In this sense, the body may also be considered an "other," as it constitutes a link between the inner world of our experiences and the outside world. The connection to phenomenology is clearly visible in Vojvodík's model: the human body is a way of "being in the world," and of "being anchored in the world." Furthermore, humans exist because they are able to experience themselves (Vojvodík, 2007, p. 29).

The anthropological model is also based on the idea that humans associate themselves with certain vertical and horizontal anthropological dimensions that are deeply rooted in humans themselves as well as in society in general. These dimensions are related to both space and the human body, and include such relations as depth-height, width-length, widening-narrowing, rising-falling, but also motion and stillness, hardness-softness, thinness-thickness, space-emptiness, multiformity-shapelessness. By perceiving their own being in terms of vertical and horizontal anthropological dimensions, relating it to space and time, and basing it on a system of signs and codes, humans have created their own way of being in the world (Vojvodík, 2007, p. 29-30).

\section{PHENOMENOLOGICAL CONCEPTIONS OF FEAR}

The 1920s and the 1930s were a time of great anxiety and constant tensions. A shadow of totalitarian reign was cast over the whole of Europe, striking fear 
into its societies. Surrealist art, especially that of the 1930s and 1940s, often reflected this loss of trust caused by the ever present fear. The main reason for this was the occupation of the Protectorate of Bohemia and Moravia by Nazi Germany. Hence, it is probable that surrealists were trying to cope with fear, by recreating a friendly alternative world in their works, even if it was to exist only within the confines of their own minds (Vojvodík, 2007, p. 52-56).

In his exploration of how surrealists represented fear in their art, Josef Vojvodík (2007, p. 52-56) throughout his works makes references to the following philosophical concepts: "fear of the world" (Weltangst), "presence of mine-ness" and "objective certainty," created by the phenomenologists Karl Jaspers, Ludwig Binswanger, Maurice Merleau-Ponty.

The first philosophical concept mentioned by J. Vojvodík (2007, p. 52-56) is the "fear of the world" (developed by Ludwig Binswanger). It refers to the unpleasant surroundings, i.e. human environment, which used to be perceived as positive or neutral, but had become a disturbed, disintegrative space, as a result of negative experiences. "Fear of the world" is visible not only in the visual and textual layer of surrealist works; the body undergoes metamorphosis: hybridization, deformation, fractalization. Furthermore, the theme of transformation of a live (and living!) body into its fragments, an object, or a shapeless, amorphous mass, is frequently present.

The concept of presence of mine-ness, proposed by Hermann Schmitz, postulates that pain and anxiety can be seen as ways of experiencing the world, or as even means of communicating with the world. In a moment of great danger (or fear), humans are focused on "here and now" and are not able to go beyond that point, as their self-preservation instincts are suppressed. As for the category of widening-narrowing, it is worth mentioning the specific types of fear that are connected with it, namely: the fear of wide-open spaces, fear of falling, and fear of dusk. The first type of fear is especially noticeable in the works of Czechoslovakian surrealists. It reveals itself as an irrational space, a boundless, ungeometrical void, which traps humans within the confines of their own bodies, not only exacerbating the feeling of fear of space, but also increasing the feeling of being restrained by one's own body (Vojvodík, 2007, p. 52-56).

On the other hand, Karl Jaspers analyzes the fear of being and existential angst. The first one is motivated by the inevitability of death - it is natural for humans to fear the end of life because it is unknown what awaits them on the other side. The other type of fear, i.e. existential angst, reaches deeper. It is the feeling of anxiety caused by the uncertainty about the meaning of life, and whether one does not waste their life away, truly living it as it should be lived. According to K. Jaspers, fear can be conquered only when one is "not afraid to be afraid" (Vojvodík, 2007, p. 55).

In the concept of fear introduced by Ludwig Binswanger, the anthropological dimensions can also function as symbols that stand for possibilities, but also for barriers to development. This is what frequently occurs when experiencing fear. In this case, the anthropological category of narrowing-widening also applies (Vojvodík, 2007, p. 55). 
In the phenomenology proposed by Maurice Marleau-Ponty, the body is not given, it is incarnated. The purpose of humans is to extend their bodies with the artifacts of their own creation. This can be observed in Nezval's poetry, in which the body disappears and something that resembles it only superficially (in shape, contour or features) takes its place. It is the paradoxical presence of the absent (Vojvodík, 2006, p. 31).

\section{SURREALIST REPRESENTATIONS OF THE BODY - SUMMARY}

To recapitulate, the body, according to its surrealist representations, has the following features:

- It undergoes a metamorphosis: fragmentation, hybridization, deformation, fractalisation. It can also be reduced to an artifact, a shapeless mass, an amalgam or something that only superficially resembles a body, thanks to its shape, contour or other features. The body is balanced on the edge between living and dead, organic and inorganic.

- It is determined by time and space.

- It can be linked to the basic vertical and horizontal anthropological dimensions. In surrealist poetry, it is most frequently falling down, into the void.

- Its functioning depends on fear, it is often shown along the narrowing-widening relation, in stupor, petrification, reduced to a flat surface or miniaturised. The feeling of being restrained by one's own body is intensified ${ }^{1}$.

\section{ANALYSIS OF VÍTĚZSLAV NEZVAL'S WORKS}

Žena v množném čísle is a book of poetry written by Vítězslava Nezvala in 1936. It shows the body as a mosaic, collage, amalgam, and phantom that frequently transforms into curious objects, both living and lifeless. By creating a chain of connections, Nezval builds pairs of contrasting worlds, e.g. one distinct and real, and the other indistinct, linked only by loose associations, or one inner and the other outer (Jelínek, 1995).

\section{BODY AS A MOSAIC}

In the works collected in Žena $v$ množném čísle, Nezval composes fantastic images of women: phantoms, unreal artificial beings, body amalgams, all transformed through fragmentarisation, fragmentation, hybridisation, deformation or fractalisation. The female body depicted in one of the poems undergoes a complete metamorphosis: from a live body/one's own body into a lifeless object, which then is anthropomorphised into a living being, to eventually

1 Own elaboration on the basis of Josef Vojvodík's reflections in Imagines corporis (2006). 
become the active speaker in the poem (Vojvodík, 2006, 336). Moreover, Nezval separates the parts of the body, rarely referring to it as a unity. In turn, he describes legs, lips, eyes, and the intimate parts, comparing them to objects.

The objects that become the constitutive parts of the body amalgam or the artificial body are the technological achievements of the time, e.g. electrical and mechanical equipment, such as watches or their parts, springs; objects connected to electricity and electrical inventions; industrial machinery; chemical reactions; inventions (a rocket, a merry-go-round, a coffee grinder, a barometer, a spice grinder, a windmill). The poetistic fascination with machines still reverberates through surrealist poetry (Stefański, 2008). However, it is imperative to note that surrealist works express not admiration but rather fear of technological inventions, which is reflected in the social atmosphere. This is also an artistic technique typical for V. Nezval: reducing the body to a machine, a lifeless object (or only seemingly lifeless, as the machines are usually depicted in motion, so there is an illusion of life), to then show it as living.

\section{BODY AS A PHANTOM}

V. Nezval also frequently shows the body as an indistinct figure, a blurry, shadowy, illusory phantom or a mirror reflection. Such a figure can be found in Nezval's poem titled Phantoms. The lyric subject of the poem directly addresses women (women as a whole, as a kind). On the one hand, the poem evokes the lyrical subject's memories of the women that he met in his life. On the other, it is an apocalyptic vision of the creation of a new kind. The poem also presents an interesting plot line - the lyrical subject undertakes several reconstructions of the image of a woman, transforming it into phantoms, delusions (which resemble a female figure and a number of objects in shape: a hat rack, bras in an illusory rising motion, a bloated shirt, a trunk with rubber legs, porcelain figurines), which then come to life, and are compared to living organisms, eventually becoming a real woman. What follows is a procession of women with oddly shaped bodies (resembling bats, a nightmarish procession, whose hands are the chains of a merry-go-round, and whose eyes are atropine), which are later destroyed and their remains resemble (or create) an image of woman in different variations, the "woman in plural".

\section{VERTICAL-HORIZONTAL}

In surrealist texts, the body is presented within a space that is no place at all, and within a completely undetermined timeframe (as in a dream or memory). Surrealists strove to break free of any spatial and temporal frames of reference. Hence, many their works leave the reader confused as to the place and time of action. By using the concepts of fear, we can come to the conclusion that the subject, gripped by the feeling of dread, stops, shrinks, and hides itself. In some of V. Nezval's texts, e.g. in the poem Propadliště, the feeling of surrealistic 
falling, plunging into nothingness, similar to vertigo, can be found. Another common theme in V. Nezval's poetry is a circular motion, like that of a mill, a coffee grinder, or a merry-go-round, which causes dizziness and confusion.

\section{BODY-CADAVER}

Absolutní hrobař [the Absolute Gravedigger] (Nezval, 2012) is a book of poetry published in 1937. In the title poem, V. Nezval creates the figure of the Absolute Gravedigger. Each of his constitutive elements is connected with a separate short story. His parts live their own lives, having little in common with a real body. Using the Gravedigger's shoes, which are a couple of lovers, a trap, and a word, as an example, Jan Mukařovský demonstrates that objects do not even resemble that what they bring into being through their own existence. They may indeed be tangentially connected to the main theme, i.e. the atmosphere of a cemetery, but they might as well be describing completely different things. J. Mukařovský also points out that the semantic balance in V. Nezval's poetry is tipped more towards objects than space, contrary to real situations, in which space is usually the focal point around which objects are built. In this place, space is devoid of its unity, and thus the objects are what create it, not the other way round (Mukařovský, 1966, pp. 275-276).

Therefore, corporeality in Absolutni hrobar is established in two main ways: by creating mosaics of dead elements (or inlaid bodies) or by giving life to lifeless elements. The destruction of this unified structure leads to increased mobility and independence of some of the elements. Importantly, the elements that Nezval uses to create the body amalgams are not alive; rot, stench, decay, and tissue necrosis are the main constituents of the mosaics shown in Absolutni hrobar. The parts affected by rigor mortis also lose the capability to undergo any metamorphosis. While the previous elements showed such potential, the objects in Absolutni hrobař are subject to degenerate, reversed laws (Vojvodík, 2007, pp. 65-66).

In poems from Absolutní hrobař, V. Nezval creates hybrids by using the remains of small animals and plants, bringing them back to life and cross-breeding them biologically. In this way, he reveals his own fear of the fragmented, crumbling world, which constantly and permanently distorts all meaning. Life seems to be in decay. It is odd, monstrous, warped by deviations (Vojvodík, 2007 , p. 66). All of the elements in this book are a way of preservation and abolition of form, showing its ambiguity, irregularity, and diversity by arranging conflicting or different objects and materials together. Shapelessness and monstrosity are the signs of the hybrid, mosaic-like, constantly dying constructions of the body and the world.

The body does not undergo any metamorphoses any more. It decays, and the process is portrayed as moldy, rotten, putrid flesh ridden with maggots, as the remains of a field mouse, or by worms, foul stench, sludge and cesspools. The language of the poems is connected with death, cemeteries and fune- 
rals. V. Nezval uses terms, such as exhumation, grave, coffin, mummification, embalming, and autopsy. What makes the Gravedigger absolute is the fact that he himself is composed of many differently-shaped forms that are alive to varying degrees.

The space-time is also warped. Space and time, the universal frame of reference for all humans that allows them to exist in a stable world and in relation to other people and objects, becomes unstable, deformed in surrealist works. This is a source of great anxiety, as it leads to the realization that, with the decay of the world and its tissue, the human body is also bound to perish, as shown in V. Nezval's Absolutní hrobař (Vojvodík, 2007, p. 69).

The poem Muž který skládá z prédmětu svou podobiznu [A Man Composing a Self-Portrait out of Objects] (Nezval, 2012) is also worth analyzing. The body shown in it is not one of a woman / of women, as it was in Nezval's first surrealist book of poetry. It functions both as a phantom (a reflection in ten windows, phantasmagorical images, anemic water beings, the process of painting a self-portrait, an unfinished image of the lyrical subject, a mermaid) and as a mosaic (as the title itself indicates, the poem is about a man, who is creating an image of himself using different objects), fragmentarisation of the body (it being broken up into pieces). It undergoes different metamorphoses (transformation of the body into two rams, becoming afflicted with a serious mental condition, going through the stages of life in order and in reverse, waking up from narcosis) and also is connected with the theme of a cemetery (burial of a dead body).

\section{CONCLUSIONS}

The period in which surrealists created their works was a time of "tragedy and poetry," when the world events inspired dread and anxiety, and were reflected in the atmosphere of the entire society. On the eve of World War II, the inevitability of which was sensed even earlier, Nezval predicted that his works and the works of other surrealists would not be understood, and perhaps be perceived to be as dangerous as the ubiquitous bacteria. On the other hand, he claims that surrealist works are created at the perfect moment, as they precisely reflect societal fears, and thus they "flourish in blood" and in "mad times." As the course of history has shown time and time again, surrealist works will probably become obsolete for future generations (as it was the case with all other artistic trends). However, V. Nezval emphasises the importance of here and now: "but today or tomorrow evening" his time will still go by, and his poetry will be an even stronger expression of this "mad century" (Nezval, 2012).

To recapitulate, surrealist poetry and other literary works contain images of the body that are connected with fear: deformations, metamorphoses, fragmentarisations, hybridisations, expressing the body as a collage, a mosaic, an amalgam, a phantom, a grotesque, an inlay, and as lifelessness. It undergoes 
multiple metamorphoses, not only within its own form, but also with regard to the categories of life and lifelessness. The women appearing in the works are frequently shown to be a part of an apocalyptic procession. They also have odd, unnatural features, composed of both natural elements and human inventions and machines. The body decays, and its parts are separated from each other and then connected again, but they never function as elements of a normal, living human being.

\section{REFERENCES}

1. Heczková, L., \& Plívová, A. (2011). Tělo, tělesnost, antropologické konstanty [Body, the Carnality and the Anthropological Constants]. In: Vojvodík, J., \& Wiendl, J. (Ed.), Heslár české avantgardy. Estetické koncepty a proměny uměleckých postupư v letech 1908-1958 [The Vocabulary of the Czech Avantgarde. Aesthetic Concepts and Changes in the Art in 1908-1958] (pp.367378). Praha: Filozofická fakulta UK v Praze, Togga.

2. Jelínek, A. (1995).Vítězslav Nezval [Vítězslav Nezval]. In: Blažíček P., Brabec J., Buriánek F., Červenka M., Grygar M., Jelínek A., at al . Dějiny české literatury [History of the Czech Literature] (pp.507-528). Praha: Victoria publishing, a. s.

3. Mukařovský, J. (1966). Studie z estetiky [Aesthetic Studies]. Praha: Odeon.

4. Nezval, V. (2012). Absolutní hrobař [The Absolute Gravedigger]. In: M. Blahynka (ed.), Básně II [Poems II], (pp.277-342) Brno: Host.

5. Nezval, V. (2012). Žena v množném čísle [Women in the Plural]. In: M. Blahynka (ed.), Básně II [Poems II] (pp. 9-46) Brno: Host.

6. Stefański, M. (2008). Karel Teige i pułapka konstruktywizmu [Karel Teige and the Trap of the Constructivism], Bohemistyka, 1-4, .94-104.

7. Vojvodík, J. (2007). Świat strachu i strach przed światem w czeskim surrealizmie lat 30. i 40 [The world of fear and the fear of world in Czech Surrealism of 1930's and I940's], Teksty Drugie, 6, 50-77.

8. Vojvodík, J. (2006). Imagines corporis. Tělo v české moderní a avantgardě [Imagines corporis. Body in czech modern avantgarde]. Brno: Host. 